\title{
The Alternative Histories of Muslim Asia's Urban Centres: De-Cosmopolitanisation and Beyond
}

\author{
MAGNUS MARSDEN
}

\begin{abstract}
Historians increasingly analyse the cultural diversity of life in the Afro-Eurasian arena of 'Muslim dominion' in terms of its cosmopolitanism. By contrast, critical scholarship has recently brought attention to declining levels of religious diversity in present-day Muslim Asia - a term that refers to Asia's Muslimmajority population zones. This article, by contrast, explores the ongoing legacy of urban cosmopolitanism in Muslim Asia. It focuses on a small but lively community of Jews from the Afghan cities of Kabul and Herat, and does so in comparison to a considerably larger community of Jews from formerly Soviet Central Asian Republics, especially Uzbekistan and Tajikistan, who identify themselves as 'Bukharan'. Investigating ethnographic material relating to Afghan and Bukharan Jewish communities based in New York, the article sheds light on an alternative and ongoing history of cosmopolitanism in Muslim Asia. More broadly, it also argues that field research amongst migrant and diasporic communities from Muslim Asia living in the West can offer important insights into the afterlives of the region's historic cities.
\end{abstract}

Keywords: city, cosmopolitanism, ethno-religious minorities, Afghanistan, commerce

This article arises out of long-term fieldwork amongst mobile Afghan merchants in a wide range of settings across Eurasia. I have conducted intensive ethnographic fieldwork with Muslim, Sikh and Hindu traders from Afghanistan in Kabul, Mazar-e Sharif and Herat, the UK, China and several countries the former Soviet Union at regular intervals since 2005. In this article, I also draw on ethnographic material gathered during a pilot study of Afghan and Central Asian Muslim Jewish communities in New York and New Jersey that I conducted in October/November 2019. The aim of this visit was to explore the

This article can be accessed at https:/ / doi.org/10.22439/cjas.v38i1.6059. 
feasibility of conducting intensive research on the afterlives of Muslim Asia's historic urban centres, many of which have witnessed the migration of both established minority and Muslim communities over the past century.

In a series of publications (e.g. Marsden forthcoming), I have argued that Afghan trading networks are ethno-linguistically and ideologically diverse. Such diversity, moreover, reflects the layered histories of the country and of its communities, imprinting itself in their structure and dynamics, as well as in the collective and individual cultural and political identities of the traders. Rather than mitigating against the cultivation of relationships of trust, such internal diversity enables traders to react and respond to the multiple geopolitical projects that affect the worlds across which they operate. Such forms of diversity, however, do not demonstrate that the legacy of historic modes of conduct for long-distance trade remain unchanged. Rather, some groups of traders have become active in long-distance trade over the past half a century, as older merchant communities, including those identifying as non-Muslim, have left Asia and established themselves in the West. In this article, I turn my attention away from groups that have maintained a role in inter-Asian commerce and connectivity and towards those that interact with the region from extra-Asian contexts.

Scholars of Muslim Asia have brought attention in recent years to the important role that cities in the region have played in mediating relationships between multiple cultures and religious traditions. Work in this vein debates the extent to which cosmopolitanism in Muslim Asia is distinctively 'Islamic' (Ahmed 2016) or better conceived of as having arisen from a complex range of cultural and religious traditions that have been simultaneously active in regions of 'Muslim dominion' (Hodgson 1993). Much scholarship has also argued that the decline of Islamic urban cosmopolitanism arose from the impact of European imperialism on premodern modes of living and managing cultural diversity (e.g. Bose and Manjapra 2010). More nuanced work, by contrast, argues that focusing on the consequences of European imperialism for Asia's cosmopolitan cultures romanticises the past and simultaneously ignores the emergence of highly diverse cities during the colonial period, especially maritime entrepôts, such as Bombay, that arose in the context of the steam revolution (Green 2018; Makdisi 2019).

As NileGreen (2016) notes, the often rather celebratory body of work on Islamic cosmopolitanism throws into sharp relief 'the stark decosmopolitanisation of Muslim Asia's cities during the twentieth cen- 
tury and postcolonial periods' - a period, he argues, that is characterised by 'an unbroken exodus of ethno-religious minorities' (Green 2016: 280; cf. Humphrey, Marsden and Skvirskaja 2009). Green (2016) uses the term 'de-cosmopolitanization' to identify the bleaching of ethnoreligious diversity in Muslim Asia's historic cities, arguing that declining levels of cultural diversity have arisen in the context of the persecution and subsequent migration of minority communities over the past century. In addition to having become less diverse in cultural and religious terms, space in Muslim Asia's cities is increasingly ordered in relationship to social, economic and ethnic boundaries - a process that has been enhanced by waves of migrants arriving in urban centres from rural regions and smaller towns, often in the context of war and persistent civil conflict.

This article seeks to contribute to debates about cosmopolitanism in Muslim Asia by suggesting that historic forms of urban cosmopolitanism continue to be injected with vitality in the cities in the West to which Asian Muslim and minority communities have migrated. It argues that the 'de-cosmopolitanization' of Muslim Asia has not unfolded in a one-dimensional or inevitable manner. Instead, ethnoreligious minorities settled in contexts in the West continue to play an important role in the transmission of cosmopolitan urban sensibilities; they also occupy an important role in the cultural imaginations of Muslim Asia's historic cities. Building on a rich body of literature that has explored the aftermath of the Ottoman Empire through the analysis of the ongoing significance of historic regions of residence to the social identity of multiple migrant communities (Loizos 1999), the article traces the relationship between ethno-religious communities no longer resident in Muslim Asia and their one-time Muslim neighbours. It emphasises, in particular, the critical role played by mobile trading communities in cultivating and maintaining nuanced modes of engaging with religious diversity. Ethnographically, the focus is on Jewish and Muslim migrants from Afghanistan and Central Asia living in the Queens borough of New York.

\section{Religious Minorities and Anxieties in Contemporary Afghanistan}

The territories making up modern day Afghanistan were home to several communities that were active in the field of commerce and did not identify as being Muslim, most prominently Jews, Hindus and 
Sikhs and Armenian Christians. Most Armenians living in Afghanistan had left the country by the early twentieth century (Lee 2002); communities of Hindus, Sikhs and Jews remained active and vibrant there until the onset of civil war in the 1990s (e.g. Levi 2002). Muslim and Jewish texts suggest that Afghanistan was home to a substantial Jewish community from the eighth century onwards, while archaeological evidence points to vibrant communities in the central cities of Firuzkuh and Ghazna in the twelfth century (Aharon 2011). In the nineteenth century, Jews in Afghanistan spoke a form of Judaeo-Persian closely resembling that of the country's Muslim inhabitants, wrote the language in the Rashi script and maintained ritual observance in Hebrew. While Jews from Iran settled in Afghanistan in the mid-nineteenth century, Afghanistan's Jews formed a distinct community that distinguished themselves from neighbouring communities in both Iran and Bukhara, collectively identifying in relation to the category 'Afghanim' (Afghan). Afghan Jews were involved in the trade of various items of great significance to regional economies, including pelt, leather and cotton (Aharon 2011). By the mid-1930s, approximately 4000 Jews lived in Afghanistan, forming a complex community mostly based in the historic cities of Kabul and Herat - smaller concentrations of Jews also lived in towns in the north (especially Balkh, Maimana and Andkhuy). Across these contexts, Jews were involved in the trade in carpets, fur and leather (Brauer 1942). During this period, Jewish communities in Afghanistan were connected to Jews living in Iranian cities, especially Mashhad (Nissimi 2003), as well as to communities in Central Asia (Bukhara) and British India (especially Peshawar, Bombay and Karachi). Despite such connections, however, the Afghanim simultaneously maintained a distinctive identity, which, as I explore below, has persisted in the context of migration from the region.

In the wake of the Bolshevik revolution of 1917, the arrival of refugees - Muslim and Jewish - from Central Asia was a source of anxiety for Kabul's political elites (Ahmed 2017). In the 1930s and 1940s, Afghanistan's rulers were suspicious of the Soviet Union but also keen to avoid antagonising their northern neighbour and enabling the case for Soviet interference. In this context, Afghanistan's rulers regarded the new wave of Central Asian refugees with suspicion, widely assuming that Jews acted as intelligence agents for the Soviet regime $\left(\mathrm{O}^{\prime} \mathrm{Halpin}\right.$ 2016). Legislation was introduced that prevented Jews from living in the towns in which they had been based in the north, resulting in most moving to the urban centres of Herat and Kabul. From 1933 onwards, 
the Afghan government also sought to reduce the commercial significance of ethno-religious minorities as part of an attempt to 'nativise' the Afghanistan economy. The government awarded monopolies of important goods to members of the ruling royal family, and Jews were forbidden from being involved in the export of key products; Jewish merchants were also required to vacate trading towns in northern Afghanistan. In later years, the government barred Jews from visiting Kabul's custom offices. Jewish families became increasingly impoverished and sought to relocate to Palestine (Koplik 2015). From 1951 onwards, Jews left Afghanistan in large numbers for Israel (Jawad 2019). 1 In the decades that followed, Afghan Jews established themselves in Israel and New York; small concentrations of Jewish families settled in Bangkok, Hong Kong and London - cities that were nodes in the global gemstone trade, a field in which Afghan Jews came to specialise. By the 1970s, approximately only one hundred Jews remained in Afghanistan; only one Afghan Jew resides in the country today (Mehrdad 2018).

The modern history of Afghanistan's ethno-religious minorities is intimately tied to the demise of the country's urban centres as seats of cosmopolitan urban living. Migrant communities did continue, however, to live in close proximity in the settings to which they moved. Having explored elsewhere how commercial relationships between Hindu, Sikh and Muslim Afghans played a critical role in the establishment of Afghan networks in Eurasia from the late 1980s onwards (Marsden 2018), I now move away from the geographic peripheries of Muslim Asia and address instead the ongoing significance of minorityMuslim relationships in diasporic relationships in the West.

\section{Muslims and Jews in New York}

Jews from Afghanistan have lived in New York since at least the 1950s, and Queens is home to approximately 1000 Jews identifying themselves as having Afghan heritage; approximately 4000 Jews of Afghan heritage live in Israel. The history of the considerably larger Bukharan Jewish presence in New York (between 50,000 and 70,000 individuals) is more recent. ${ }^{2}$ It mostly comprises two waves of migrants: first, Jews from Central Asia who moved to the USA from the Soviet Union in the 1980s; and, second, a newer wave of migrants that established themselves in the city after the collapse of the Soviet Union in 1991 (Loy 2016). 
New York and the nearby state of New Jersey are also home to established communities of Muslims from Afghanistan and Central Asia. From the 1930s onwards, New York played a critical role in Afghanistan's economy (Crews 2015). Afghan merchants were based in New York where they were actively engaged in Afghanistan's fur trade. They maintained bank accounts in the city, and such merchants formed the basis of the country's foreign currency reserves. Afghan trading companies - Jewish and Muslim - maintained offices in the city; these were involved in the import of products to the USA, and, especially in the case of Afghanistan's Jewish merchants, the provision of credit lines to Muslim import-exporters based in Afghanistan. In the 1950s, Afghan Muslim students travelled to America on bursaries provided by the US government: several settled in the country and established what would become nodes for communities that grew over the decades to come. For example, in the 1970s, well-to-do Afghan merchants moved their capital outside of Afghanistan as the political situation inside the country worsened in the context of the rising tensions of the Cold War. In New York and New Jersey, Afghan migrants included families that identified themselves as 'Bukharan', having fled Central Asia in the 1920s (Marsden 2018). As a result, Muslim migrants to New York from Afghanistan shared a connected cultural and geographical background with the city's Central Asian Jewish communities.

Muslim migrants from Central Asia settled in the city during the 1950s and in the context of Cold War migrations: these migrants largely comprised families that had left Central Asia in the 1920s for Afghanistan and Turkey, relocating to the USA in the 1950s. Such migrants established organisations, such as the Turkestanian American association - a 'pan-Turkic' organisation that lobbied, from the late 1950s onwards, for the government of the USA to play an active role in the 'liberation' of Central Asia's Muslims. ${ }^{3}$ In the 2000s, migration to New York from Central Asia expanded exponentially and mostly comprised of the citizens of Uzbekistan and Tajikistan. ${ }^{4}$ This wave of migration largely arose through the USA's 'green card lottery scheme'. A group that navigated this scheme with especial success is the city of Samarqand's Muslim inhabitants. Many Samarqandis initially migrated to South Korea as industrial labourers and were able to secure access to green cards via the lottery system because of this prior migration experience (Massot 2013). Muslims from the city of Samarqand - mostly speakers of the 'Tajiki' form of Persian - now form a sizeable community in Brooklyn and in Philadelphia, both 
locales in which earlier generations of migrants from Central Asia lived. As Howell has shown, Detroit's Arab communities comprise a complex mix of Muslim and Christian communities that shared histories of co-residence in Ottoman cities (Howell 2014). Similarly, Muslim and Jewish migrants from Afghanistan in particular and Central Asia in general in the city share a common historical, cultural and geographical background.

\section{Ethno-Religious Minorities and the Cultural Imagination in Global Afghanistan}

Over the past four decades, Afghanistan has come to be associated in scholarly and more popular discourse with ultra-conservative forms of Islam - including those espoused by the Taliban and more recently ISIS. There is little if any place for non-Muslim minorities in Islamist imaginaries of either the Afghan nation or Muslim identity for non-Muslim minorities; indeed, Islamists in Afghanistan as elsewhere are often directly hostile to the forging of social, commercial and emotional relationships between Muslim and non-Muslims. In the final months of the Taliban's rule of Afghanistan between 1995 and 2001, for example, legislation was introduced that purposefully targeted the country's remaining ethno-religious minorities, especially its Sikh and Hindu communities who were required to wear yellow clothes and turbans and to fly yellow flags outside their houses and shops in order to publicly identify themselves. ${ }^{5}$

Hostility toward ethno-religious minorities in Afghanistan is not confined to active participants in Islamist movements such as ISIS and the Taliban; it is, rather, a pervasive aspect of everyday life. I have often encountered animosity towards ethno-religious minority communities while conducting research in the country. For instance, after I told a Kabul-based money exchange agent in September 2018 that I had spent the day visiting Hindu and Sikh Afghans in the 'old city' (shahr-e kohna), he told me that, 'they should return to India - that is where they are from'. The man's remark is a reflection of the extent to which an exclusive form of autochthonous nationalism in which claims to belonging made on the basis of being from the 'soil' (khaq) are a prevalent feature of Afghan political discourse.

At the same time, I have also seen how Afghans from a variety of backgrounds hold and foster a deep interest in the past presence of ethno-religious minority communities in the country. Many peo- 
ple whom I spoke with in the country were keen to discover what had happened to the country's religious minorities after they left Afghanistan. In the historic city of Herat in western Afghanistan, for example, I visited along with a local host a neighbourhood that had formerly been a site of Jewish community life. My host took me to a synagogue (renovated in the 2010s by the Aga Khan Trust for Culture) and a Jewish bathhouse. During a later visit to Herat, I visited the city's Jewish cemetery and was shown tombstones recently renovated with the support of Afghan Jews who had travelled to the city from North America.

My visit to the neighbourhood prompted me to explore various forms of cultural production by Afghans in the country and its diasporas concerning the country's Jewish community. Afghan travellers to the city, I discovered, had written internet blogs about Herat's Jewish community: these blogs and other pieces by journalists advocated 'the Jewish street' (koocha-ye musaahia) as a must-see place for Afghan tourists visiting Herat. As in other parts of the world, Afghanistan's cultural elite regard acts of positively identifying with the country's historic cultural diversity as an effective way of demonstrating open-mindedness and cultural sophistication (motamidin).

My Afghan Muslim friends living in the diaspora in Europe also introduced me to compatriots of Muslim heritage who had developed a key interest in the country's Jewish communities and were conducting independent research into them. Some of these diasporic 'organic intellectuals' had even travelled to Israel to meet members of the country's Afghan Jewish community. One man in his fifties told me that he had made an initial visit to Israel because his doctor had suggested that swimming in the Dead Sea would help cure his skin condition. During the trip, however, he had met a family of Afghan Jews on the beach, and since then had travelled regularly to Israel in pursuit of knowledge about the community.

The history of Afghanistan's religiously diverse past is important not only for exiled cultural elites who live in Europe and America: research institutions in Afghanistan have also played an active role of bringing attention to this aspect of Afghan history within and beyond the country. In Kabul, for example, I was invited by the Afghan Institute of Strategic Studies - a leading think tank and research organisation with close ties to the western city of Herat - to an event they had organised in order to celebrate the lives of Nelson Mandela, Mahatma Ghandi and Afghanistan's religious diversity. In front of a gathering of Kabul-based Afghan 
politicians and dignitaries, films on the Afghanistan's ethno-religious minorities were screened, whilst a representative of Afghanistan's dwindling Sikh and Hindu communities spoke about the difficulties in the country faced by its 'minority communities' today.

Afghan officials have also actively promoted discourses that emphasise the country's religiously plural history and the importance of knowledge about this history for future generations of Afghans. In a book written in Persian entitled, Be the Provider of Relief, Not an Inquisitor of Relief, the current Ambassador of Afghanistan to Great Britain and Northern Ireland (Said Tayeb Jawad) asks why such little prominence has been given to the study of Afghanistan's Jews by both historians from the country and among scholars based in Europe and America (Jawad 2019). Jawad also emphasises the similarities between Afghan Jews and Muslims both in the past and the present, arguing that both groups are characterised by religious conservativism and by a profound sense of attachment to their 'homeland' in the context of dispersal and migration.

Members of the country's ethno-religious minorities actively reflect on such discourses, and do so in diverse ways. As we shall see in a following section, in diaspora settings, Afghan Jews have cultivated close relationships with sympathetic Afghan Muslim officials and organic intellectuals based in the cities in which they live. Yet for communities such as the country's Hindus and Sikhs that maintain a presence in the country, relationships with officials and official discourses are more strained. In July 2018 and August 2019, I met with over 30 members of the Sikh and Hindu communities, as well as several representatives of their representatives in Kabul. An issue that frequently arose in our conversations was the nature of official discourse about the community. A representative of Afghanistan's Sikh community in Kabul, for example, told me that while Afghan officials praised his community's contribution to the country and introduced legislation designed to improve the situation of remaining families, they treated the community as a 'jewel' to be protected rather than a living aspect of Afghan society and economy. Notions of heritage driven by international organisations and actors regularly deny agency to communities directly implicated by such processes (Salemink 2016; cf. Herzfeld 2009); in the case of Afghanistan, this is something consciously reflected upon by the country's remaining Sikh and Hindu communities.

In Afghanistan and within the country's diaspora, there has been an interest amongst the elite in historic expressions of cultural and religious 
diversity. This has resulted in forms of cultural production - including posts, articles, online videos, professionally produced documentaries and published books - that have circulated widely amongst Afghans at home and abroad, also as a source of comment, reflection and debate.

\section{The Afghan Jewish Community in Queens, New York}

The Queens borough of New York is home to the only functioning Afghan Jewish synagogue outside of Israel. The synagogue was founded in 1977, at which time it was located in the basement of a house of one of the congregants. While Afghan Jews had lived in New York since the 1940s, synagogue documents depict earlier migrants as having lived 'scattered' and 'rootless' lives, leading many to 'drift away from their culture and religion'. Two decades after the community had begun gathering in the basement, the synagogue moved to a nearby structure built for this purpose. Afghanim largely manage the synagogue, and several of its congregants identify themselves as Herati or Kabuli, yet it officially refers to itself as a 'Sephardic-Afghan' institution, attracting worshippers from the borough's Sephardic communities. The term Sephardi refers to Jews who are the descendants of Ladino-speakers who migrated to Turkey and the Middle East after their expulsion from medieval Spain. According to Aharon (2011), the decision among Afghan Jews (who neither speak Ladino nor are emigrants from Spain) to affiliate with the broader Sephardi community, reflects a process of 'ethnicisation', whereby migrant communities absorb labels that are utilised in the United States. Given the very small size of the community, the embrace of the category Sephardi, she argues, enabled Afghan Jews to distinguish itself from European Ashkenazi communities while remaining viable.

During my visits to the synagogue, I met congregants who traced their ancestry to Herat and Kabul, but also to Mumbai, Cochin and Peshawar in South Asia, Bukhara and Samarqand in Central Asia, as well as Yemen in the Arabian Peninsula. Indeed, the synagogue's current Rabbi is neither Kabuli nor Herati but Bukharan. Attracting a diverse cross-section of worshippers is important for very small communities. By not restricting membership, synagogues ensure a firmer foundation since they derive their finances mostly from donations made by members of the congregation. At the same time, expanding the congregation in this way also places an imperative on ensuring the ongoing significance of Jews from Afghanistan on the synagogues' 
management in order to ensure its continuing ability to function as a site of community identity and sociality.

Most of the synagogue's congregants left Afghanistan in the 1950s, often initially spending time in Israel before eventually moving to New York. The migration trajectories of some Afghan Jews also passed through Britain where Jews holding Afghan passports had been residents since at least the 1930s (Koplik 2015). A small number of Afghan Jewish merchants operate fur, carpet and antique businesses in Britain, and several Afghan Jews studied in the country in the 1950s and 1960s - merchants from the country acted as the guardians of the young students. Between 1934 and 1967, the Whittingehame College for Boys operated as a fee-paying Jewish boarding school located close to England's South Coast (Shanes 2000). Initially, the school largely attracted British Jews and those from central Europe (including several whose parents sent them to the UK from Europe). During the 1950s, however, an increasing number of Jewish boys from Muslim Asia especially Iran, Turkey and Afghanistan - attended the school; indeed, the school also admitted and sought to attract Muslim students during this period. Having completed their study in Britain, most Afghan Jewish students at the school relocated to establish businesses or to live with their families in New York.

A handful of the Afghan congregants in New York continued to live and conduct business in Afghanistan in the 1970s and early 1980s. One congregant with whom I spoke, for instance, had lived in Afghanistan in the 1970s after returning to the country from the USA when his mother had requested that he travel with her to Afghanistan after she felt homesick for the country in which she had lived with her husband who had died in New York. Another congregant had lived in Afghanistan until the mid-1980s and studied a science subject at Kabul University before her family decided they should leave. Initially the family travelled to Karachi, where they stayed for some time before one of the city's remaining Jewish families assisted them in travelling to Switzerland from where they were able to travel to Israel. None of the Jews I spoke with during my visits to the synagogue had returned to Afghanistan after the 1980s, though several did say they would be keen to visit the country if conditions allowed. I am aware of Jews travelling to Afghanistan from elsewhere in North America, mostly in order to oversee the restoration of historic sites by international organisations (such as the Aga Khan Trust for Culture) and to play an active role in the restoration of Jewish 
cemeteries in the country. Decades have passed since most members of the congregation left Afghanistan, yet many Afghan Jews living in New York continue to discuss their memories of life in the country with one another.

Many of New York's Afghan Jews work on the 47th street in Manhattan, an international centre for the sale of precious stones and gems (Shield 2003). In their offices, they work in close proximity to many Ashkenazi merchants also involved in the trade, as well as to non-Jewish traders (especially from India). Some traders have built impressive businesses, selling branded jewellery lines and globally procuring precious stones, including diamonds. One Afghan Jew in the city told me that at one point his family maintained officers in the USA, the UK, Thailand and Japan, and were able to trade 24 hours a day. Today, he makes relatively frequent trips to the Russian city of St Petersburg, a critical node in the global diamond trade. It is also clear that the trade in precious stones has undergone significant transformations, and that the forms of connectivity and mobility once important to traders have declined in significance. In particular, the growing importance of conducting business ethically and in a legally regulated manner has reduced the significance of mobility for the transport of stones between significant nodes in the network. An Afghan Jew who identified himself as being 'Herati' remarked that he had previously often travelled to Hatton Cross - a street comprising several jewellery and precious stone merchant offices in central London - but that changes in the nature of the trade meant he rarely travelled to London anymore.

If Jews born in Afghanistan are currently largely engaged in the sale of precious stones and gemstones, their proficiency in this is informed, no doubt, by the similarly transnational nature of their earlier business activities. In the 1950s, The London Gazette lists Afghan Jews based in the city as being 'fur merchants' and 'seamstresses' - they were involved in the import of karakul wool but also of 'Afghan suede jackets' - a well-known fashion item in London until the 1970s that was even worn by cultural icons of the era, including members of the Beatles. Indeed, a merchant of Kabuli Jewish background based in New York told me that he had been involved in the import of suede coats from Afghanistan. He also innovated the business by opening a factory in Istanbul at which higher quality suede was prepared and stitched before being exported to the West. During this period, Jewish merchants from Afghanistan and Central Asia based in London also dealt in carpets and antiques. Such merchants maintained close connections 
with visiting Afghan Muslim merchants and officials, as well as Soviet trade delegations. In order to maintain such connections, they used their skills in the domain of 'gastro-diplomacy' (Henig 2016). Lilian Cordell, whose father was a Bukharan Jewish antique and carpet trader in London, for example, has written of how her Bukharan Jewish mother offered hospitality to visiting traders and officials, providing famed Afghan dishes to Muslim guests and Central Asian and Russian cuisine to Soviet officials (Cordell 2017).

Further research into the experiences of second-generation Afghan Jews is required. Second-generation Jews of Afghan descent in New York are not, however, especially active in the gemstone trade. Afghanborn members of the Afghan Jewish community with whom I spoke told me that their children, and those of others in the community, were more likely to be involved in the real estate business or to work in professional jobs than play an active role in the gemstone business. The same category of respondent also remarked that second generation Afghan Jews have mostly opted to not marry members of the Afghan Jewish community but, instead, found partners of Jewish background, both Sephardi and Ashkenazi. None of the Afghan-born Jews with whom I spoke were especially concerned about the implications that such patterns of marriage would have for the future of their community; they emphasised rather the paramount importance of inter-marriage within the Jewish faith. As both participation within the gemstone trade and marriage within the community decline, it appears that the only ongoing sources of vitality for Afghan Jewish trading networks and cultural institutions will decline in significance. Other non-Ashkenazi Jewish communities that have emigrated from Muslim Asia - including Bukharan but also Aleppine Jews - have not faced this development, presumably due to the larger size of their respective communities. In this context, the effort invested by elder members of the community into maintaining community institutions, seeking recognition for the community in the USA and amongst Jews globally and transmitting cultural knowledge to younger generations is injected with further significance more generally, especially for the specific individuals involved.

A brief online survey of cultural production by second and third generation Jews of Afghan heritage in the USA does indeed point to curiosity amongst this age group about their past. Women born of Afghan Jewish immigrants to the USA have written PhD theses on the community and cookery books that reimagine old Afghan Jew- 
ish and 'Silk Road cuisine' in relation to new culinary trends, mostly vegan in nature (Abraham-Klein 2014). Elders in the community are concerned, however, that youngergenerations had a poor and sometimes inaccurate understanding of Afghanistan's Jewish past. A well-known Hollywood actor of Afghan Jewish background, for example, was purported to have said that his ancestors were 'nomadic South Asian Jews'. This was much to the chagrin of my informant in New York who remarked to me, 'It's complete nonsense! I know his grandfather; they were Heratis from one of Asia's oldest cities! Nomads!' Similarly, younger members of the community are also criticised for writing about the life of Jews in Afghanistan inaccurately. One woman, an Afghan Jew told me, had written that Afghan Jews shared apartment buildings with Muslim families: 'There were no apartments when we lived in Afghanistan, and our women, like those of the Muslims, did not reveal their faces to non-relatives'.

Other Jewish communities in the USA appear to have either integrated in wider Jewish society or fashioned distinct communities in relation to particular expressions of Judaism (Zenner 2000). By contrast, the Afghan Jewish community, perhaps because of its size, appears to be capable of maintaining a distinctive identity while at the same time emphasising the strength of its connections to other groups as well as its significance to Judaism more generally. Afghan Jews in New York often emphasise that because they are descendants of the Babylonian rather than Roman exodus, they have kept Jewish scripture, knowledge and ritual alive over several more centuries than European Ashkenazi Jews. At the same time, they also emphasise their ability to make connections with other Jewish groups and, as a result, represent the whole of Jewish identity in a unique and universal manner. As an Afghan Jew in New York aged in his early 70s remarked to me, 'My mother's family is from Bukhara, I'm from Kabul and I also have connections to Mashadi Jews and my wife is an Ashkenazi - I'm a truly global Jew'.

\section{Dynamics of Coexistence (1): Afghan Jews and Muslims}

The twentieth and twenty-first century history of Afghanistan's Jews, then, is one of gradual spatial and cultural distance from Afghanistan. This trend is likely to increase in the future as new generations of Afghan Jews marry into different Jewish communities and the community dissipates as a result. Interactions between Jewish and 
Muslims Afghans between the 1950s and present day have not, however, been confined to the realm of nostalgia and memory alone.

The fact that many Afghan Jews in New York are engaged in the sale of precious and semi-precious stones results in interactions between them and traders based in Afghanistan, especially since the country is a significant source of several stones, including rubies (yaqut), ruby spinel (la'al), emeralds (zamarud), tourmaline (beruj) and lapis (lajuward). Merchants in Afghanistan are involved in the transportation and sale of gemstones to major centres in the market, especially in Bangkok, Dubai, Hong Kong and other cities in southern China and St Petersburg. Afghan Jewish merchants with whom I interacted in New York, for instance, told me that Muslim Afghans bring samples of emeralds and rubies to their offices in New York. Due to the manner in which stones are mined and regulated in Afghanistan, however, they told me that such meetings rarely result in purchases. On hearing that I was in New York spending time with Jews from Afghanistan, an Afghan Muslim merchant based in China I know immediately sent me pictures of emeralds in his possession, and asked if I could show them to my new 'friends' and broker a deal.

Afghan Jews in New York also interact and forge relationships with Afghanistan's diplomats in the USA. As I have explored elsewhere, the ability to navigate complex geopolitical contexts and to establish enduring relationships with formal diplomats is essential to success in long-distance trade (Marsden forthcoming). A former Ambassador for Afghanistan in the USA, for example, cultivated a close relationship with Afghan Jews based in New York; he even wrote a book in Persian that explored the community's history (Jawad 2019). At the same time, prominent Afghan Jewish merchants also maintain connections with Afghanistan's diplomatic missions in the USA. During my visit to New York, for example, a Kabuli Jewish merchant told me that he had hosted Afghan officials in his upmarket jewellery office on the same day I visited him; amongst the topics they discussed were how to support a brilliant young Muslim student from Afghanistan who wished to conduct scholarship on the politics of water. The Kabuli Jewish merchant had suggested using his connections in Israel to secure government funding that would enable the young student to study at one of the country's universities. Indeed, interactions between Afghan Jews in New York and diplomats from Afghanistan also bring the broader communities into direct and face-to-face contact with one another. I have seen, for instance, photographs of dinners organised in New 
York to celebrate Afghan Jewish history that were attended by Afghan Jewish and Muslim families.

An expanding body of anthropological and historical literature has brought attention to the entanglements of commercial networks and practices of philanthropy. Studies of philanthropy in South Asia, for instance, document the extent to which ethno-religious minorities, such as Bombay's Parsis and Ismaili Muslims, played a central role in the emergence of modern philanthropic practices (Green 2015). Queens' Afghan Jews interact with Muslims from the country in the philanthropic domain. If Afghan Jews based in New York rarely if ever travel to Afghanistan, then they have been involved in the delivery of 'humanitarian assistance' to people in Afghanistan. There is also an extensive body of literature exploring the significance of communitybased philanthropy to Jewish migration and to practices relating to the preservation of Jewish built heritage (e.g. Driver 2018). For example, Afghan Jews in New York have supported the single remaining Jew in the country, by supplying the Jewish ritual foods required for marking the celebration of Passover. Similarly, Afghan Jews living in North America have also travelled to Herat in order to restore the city's Jewish cemetery.

While Afghan Jews based in New York have been involved in philanthropic activities relating to the Afghan Jewish community, they have also assisted in raising money to support humanitarian activities relating to Afghan Muslims living in Afghanistan and Pakistan. In particular, Afghan Jews have been active in a scheme that facilitates the travel to Israel of Afghan children who suffer from debilitating health conditions for surgery and treatment. This scheme is publicised widely in the print and online media, yet the identities of the actors involved as well as its recipients remain confidential due to a fear in Afghanistan of reprisals on families that agreed for their children to travel to Israel. In this scheme, children fly to Turkey from where those who are involved arrange onward travel to Israel. Despite Israel and Afghanistan not having diplomatic relations, Israeli visas have been issued to Afghans travelling to the country on this scheme. In Israel, Afghan-speaking Jews living in the country, as well as Urdu-speaking Jews who migrated to Israel from India, support these children and their parents (see Lieber 2017).

During the 1980s, children from Afghanistan regularly crossed international borders without proper travel documents on journeys that were justified in relation to 'humanitarianism', especially on the part of 
the USA and the USSR. Thousands of children from Afghanistan, many of whom had lost parents in the conflict, travelled to the Soviet Union as part of bi-national agreements where they studied in boarding schools. A small number of Afghan children flew from Pakistan to Texas for reconstructive surgery and 'trauma counselling'. The international mobility of such children was justified in relation to humanitarian efforts but was premised on the construction of 'medicalised subjectivities' in which Afghans were depicted as victims of trauma, thereby motivating further 'humanitarian' interventions (Nunan 2016: 131-132).

\section{Dynamics of Co-existence (2): Food and Restaurants}

In Central Asia, long-distance trade is intimately connected to institutions ranging from caravanserais to teahouses that provide commercial forms of hospitality to mobile merchants. In the contemporary context, Central Asians are often visible features of the culinary landscapes of inter-Asian commercial hubs, running teahouses, restaurants and hotels in trade hubs such as Dubai and Jeddah in the Arabian Peninsula and Yiwu in China. It is not, therefore, surprising that a reason for which New Yorkers generally know the Rego Park area of Queens is for the preponderance of Bukharan Jewish restaurants found there. Kosher eateries and groceries selling Afghan and Central Asian staples - including baked breads, dried fruits, nuts, as well as bottles of brandy - jostle side-by-side one another. At first sight, such businesses mark the distinctly Jewish environment of the neighbourhood. Indeed, much literature on food and identity in Jewish communities dwells on its significance for the building of bounded religious identities and communities (Cooper 2012). A closer look at such businesses, however, reveals that the social and religious dynamics of this neighbourhood are more complex. While Jewish merchants overwhelmingly own restaurants and shops, Muslims born in Uzbekistan who live in New York and are migrants from Samarqand often staff these shops. Moreover, if the shops in which kosher goods are sold are Jewish, then those who supply them with exquisite dried fruit and nuts from Central Asia and Afghanistan are as likely to be Muslim as they are Jewish.

Having been invited to spend a day visiting Bukharan synagogues with one of the Afghan Jews I had met at the largely Afghan synagogue I discovered would not open until later in the day, my host decided to take me to visit a grocery store in a nearby neighbourhood owned by an Afghan Muslim. Posters of famous landmarks in Afghanistan adorned 
the shop's walls, while the music of Ahmed Zahir (a famed Afghan musician of the 1960s who died in 1979) played in the backdrop. My Jewish host was immediately greeted by the Muslim owner of the shop, 'Look who's come!' the shopkeeper shouted out, 'Where have you been? I haven't seen you in a long while'. Amidst purchasing dried nuts and raisins imported to the USA from Afghanistan, a steady conversation proceeded in Dari between the two men about the music of Ahmed Zahir. The shopkeeper informed his customer of the arrival on Kabul's scene of a musician who sang so similarly to Ahmed Zahir that it was impossible to distinguish their voices from one another. Encounters such as these reveal how, in this neighbourhood, shared memories of life in Kabul, as well as knowledge about recent developments in the city, circulate amongst both Jewish and Muslim emigres.

During my stay in the Rego Park neighbourhood, I mostly dined at Bukharan kosher restaurants, and regularly bumped into congregants at the Afghan synagogue in the course of doing so. Such eateries included cafes serving traditional Bukharan dishes - plov (spiced rice cooked with meat, carrots and raisins), sambusa (pastries filled with meant and onions), mantu (a type of meat filled pasta dumpling) and salads. There are also several more upmarket establishments that dished out delicacies including marinated kebab that could be eaten with a glass of wine or a few hundred grams of vodka. Bukharan Jews who had previously lived in Tajikistan, especially the cities of Dushanbe and Khujand, owned many of the larger restaurants in the Rego Park area, which were invariably full with diners from $6 \mathrm{pm}$ onwards. The waitresses employed to serve guests, however, largely identified themselves as being from the city of Samarqand and were Muslim rather Jewish in terms of their religious affiliation. As in the case of the grocery stores, in restaurants too, old neighbours from Central Asia entered into employee-worker relationships with one another in New York.

Amongst the smaller cafes I frequented was one whose owner was Jewish and from Samarqand. He had spent most of his life in Moscow, where he ran cafes and restaurants serving Uzbek food, and had lived in New York for around seven years. Over this period, he had managed to open a café which specialised in plov and sambusas cooked in ovens (tandir) that the owner had imported to New York directly from Uzbekistan. The clientele at the café was diverse, though mainly 'Central Asian' in one shape or form. I shared a table with two Muslims from Samarqand who chatted with the cafe owner about the glories of Samarqandi culture and how their culture made all of them - Jew or 
Muslim - distinct from others. The men agreed as they shared teacups of vodka poured from a mineral water bottle, that they were above all Samarqandi rather than 'Tajik' or 'Uzbek'. The three men talked freely to one another in the Samarqandi dialect of Persian and laughed as the patron of the establishment changed the wording of a famous poem about the twin cities of Samarqand and Bukhara. While the poem usually says that Bukhara is the sacred city of Islam, the restaurateur changed it to become a sacred seat of the Jews. A Rabbi who was peeling spring onions watched the conversation from another table; his overall role was to see that the restaurant's Muslim chefs ensured kosher standards were maintained. Unable to speak the dialect of Persian in which we spoke, the owner of the café told me that the Rabbis' parents were from Tajikistan but that he had been brought up in Israel and so could speak Russian, Hebrew and English, but not Tajiki.

\section{Conclusion}

This article has documented the lived relationships between diasporic groups that share histories of co-habitation in Muslim Asia's historic cities yet identify with different religious traditions. The notion of 'Muslim Asia' it has deployed is complex and internally diverse and builds on scholarship that has emphasised the complex rather than reductive role that Islam has played in connecting disparate parts of the world to another (Ahmed 2016; Hodgson 1993). By exploring comparative yet connected cities in Muslim Asia, I have emphasised the diverse legacy of histories of cohabitation in the present and questioned the validity of conceiving of Muslim Asia as an internally homogenous space. Modern national and geo-political histories, as well as the economic systems with which they are entangled, have resulted in connected communities undergoing divergent histories. At the same time, however, the concept of Muslim Asia is helpful because it transcends the limitations of narrow area studies frameworks and brings attention to the ongoing significance of wider connective histories. This legacy is especially striking in relation to the material presented in this article, because it concerns categories of actors - ethno-religious minorities and the political and cultural elites of Afghanistan - both of which are widely treated within and beyond scholarship as being peripheral to Muslim Asia. Exploring the active role played by such groups and contexts in the production of knowledge questions taken-for-granted assumptions about the geography of Muslim Asia's political and economic centres, 
and the assumed forms of influence that opinion formers within these ranging from religious scholars to militants and political figures - have over the wider region.

An extensive body of scholarship exists on mobile Jewish, Hin$\mathrm{du}$ and Sikh migrant communities, yet few studies explore the relationships that connect these to historic cities and their Muslim inhabitants. This article has illuminated, instead, the lived nature of relationships between different communities that shared an identification with particular urban backgrounds. Exploring the significance of attachment to urban locality for the identity formations of multiple communities dispersed through space raises the possibility of developing a new and different understanding of the dynamics of diasporic existence, sociality and identity. It is hard to dispute the 'de-cosmopolitanization' of Muslim Asia's cities. Yet in diasporic settings in the West, interreligious social worlds have been maintained through formal and informal diplomacy, trading activities and sensibilities produced through the shared consumption of music and food. Such interreligious social worlds also inform debates about religious plurality in Muslim Asia as a result of the cultural activities of officials, cultural elites and organic intellectuals, as well as the ties that both Muslim and minority communities have sought to maintain with their cities of origin.

Colonial regimes reified distinctions between majority and minority populations and erected community boundaries in what had previously been fluid social and cultural environments, and secular ideologies enhanced these by shaping religion's place in public life (Mahmood 2015). Rather than identifying explicit projects that celebrate religious diversity, or assuming that religion inevitably is central to identity (including of diaspora communities), the ethnographic material presented in this article bring into view tacit, implicit and practical modes of interacting across markers of religious difference. There is scope for further analysis of forms of identification that have tended to be neglected in the study of Muslim Asia to date, especially those which transcend the bounds of confessional adherence but at the same time do not embrace a secular worldview. The ability of the Bukharan Jewish restaurateur from Samarqand to replace Islam with Judaism in a poem underscoring the city's spiritual significance is one example of this mode of identification. A study of such forms of identification will offer critical insights into the shifting relationship of different parts of this cultural space to one another and, indeed, to the wider world. 


\section{ACKNOWLEDGEMENTS}

The research work on which this article is based was supported by the European Research Council (ERC) under the European Union's Horizon 2020 research and innovation programme 669132 - TRODITIES. Thanks to Vera Skvirskaja, Paul Anderson, and David Henig for comments on earlier drafts.

Magnus Marsden is Professor of Social Anthropology and Director of the Asia Centre at the School of Global Studies, University of Sussex. He is the author of several ethnographic monographs, including, most recently Trading Worlds: Afghan Merchants across Modern Frontiers (Oxford, 2016). E-mail:m.marsden@sussex.ac.uk.

\section{NOTES}

1 For a first-hand account of such policies and their effects on Jewish merchants, see Jalallar 2012.

2 The term refers to the Central Asian Emirate of Bukhara that was home to substantial communities of Jews speaking a form of Judaeo-Persian. Jews identifying their origins in the territories of the former Emirate of Bukhara refer to themselves using the term, 'Bukharian'. For the sake of clarity, I henceforth use the category 'Bukharan Jew'.

3 Isakjan Nazirkul (President of the Turkestanian-American Association), letter to Daniel J. Flood (Congress of the United States, House of Representatives), 3 April 1961, Congressional Record. See also Fein 1984 and, on the association's relationship to Pan-Turkic activities more broadly, Landau 1995.

4 The New York Times reported that in 2000, Brooklyn was home to 5033 Uzbekistan-born residents; by 2015, the number had risen to 13,651 (Robbins 2017).

5 On Afghanistan's Sikh and Hindu communities, see Hanifi 2012. On their modern economic and political fortunes, see Foschini 2013 and Fry 1974.

\section{REFERENCES}

Aharon, Sara 2011. From Kabul to Queens: The Jews of Afghanistan and their Move to the United States. New York: Decalogue Books/American Sephardi Foundation.

Ahmed, Faiz 2017. Afghanistan Rising: Islamic Law and Statecraft between the Ottoman and British Empire. Cambridge, MA: Harvard University Press, 2017.

Ahmed, Shahab 2016. What is Islam?: The Importance of Being Islamic. Princeton, NJ: Princeton University Press. 
Bose, Sugata and Kris Manjapra (eds) 2010. Cosmopolitan Thought Zones: South Asia and the Global Circulation of Ideas. New York: Palgrave Macmillan.

Brauer, Erich 1942. 'The Jews of Afghanistan: An Anthropological Report'. Jewish Social Studies 4 (2): 121-138.

Cooper, Allana E. 2012. Bukharan Jews and the Dynamics of Global Judaism. Bloomington: Indiana University Press.

Crews, Robert D. 2015. Afghan Modern: The History of a Global Nation. Cambridge, MA: Harvard University Press.

Driver, Cory 2018. Muslim Custodians of Jewish Spaces in Morocco: Drinking the Milk of Trust. Dodrecht: Springer.

Foschini, Fabrizio 2013. 'The Other Fold of the Turban: Afghanistan's Hindus and Sikhs'. Afghanistan Analysts Network, 23 September. Kabul: https://www.afghanistan-analysts.org/en/reports/ rights-freedom/the-other-fold-of-the-turban-afghanistans-hindusand-sikhs/.

Fry, Maxwell J. 1974. The Afghan Economy: Money, Finance, and the Critical Constraints to Economic Eevelopment. Leiden: Brill.

Green, Nile 2015. Terrains of Exchange: Religious Economies of Global Islam. London: Hurst and Co.

Green, Nile 2016. 'The Demographics of Dystopia: The Muslim City in Asia's Future'. History and Anthropology 27 (3): 273-295.

Green, Nile 2018. 'The Waves of Heterotopia: Toward a Vernacular Intellectual History of the Indian Ocean'. American Historical Review 123 (3), 846-874.

Hanifi, Shah Mahmoud 2012. Connecting Histories in Afghanistan. Stanford: Stanford University Press.

Henig, David 2016. 'Hospitality as Diplomacy in Post-Cosmopolitan Urban Spaces: Dervish Lodges and Sofra-Diplomacy in Post-War Bosnia-Herzegovina'. Cambridge Anthropology 34 (2): 76 -92.

Herzfeld, Michael 2009. Evicted from Eternity: The Restructuring of Modern Rome. Chicago: University of Chicago Press.

Ho, Engseng 2017. 'Inter-Asian Concepts for Mobile Societies'. Journal of Asian Studies 76 (4): 907-928.

Hodgson, Marshall G.S. 1993. Rethinking World History: Essays on Europe, Islam and World History. Cambridge: Cambridge University Press.

Howell, Sally 2014. Old Islam in Detroit: Rediscovering the Muslim American Past. New York: Oxford University Press.

Humphrey, Caroline, Marsden, Magnus and Skvirskaja, Vera. 2009. 'Cosmopolitanism and the City: Interaction and Coexistence in 
Bukhara'. In S. Mayaram (ed.) The Other Global City. New York: Routledge, pp. 202-232.

Jawad, Said Tayyeb 2019. Nnash Dehaid ve Eymanash Maporsaid: Chand Justar-e dar Gostere-ye Adab, Tarikh ve Tassawuf (Be a Provider of Relief, not an Inquisitor of Belief: Essays on Ethics, History and Sufism). Kabul: Amiri Publications.

Koplik, Sara 2015. A Political and Economic History of the Jews of Afghanistan. Leiden: Brill.

Landau, Jacob M. 1995. Pan-Turkism: From Irredentism to Cooperation, London: C. Hurst and Co.

Lee, Jonathan 2002. 'The Armenians of Kabul and Afghanistan: Cairo to Kabul'. Afghan and Islamic Studies.

Levi, Scott C. 2002. The Indian Diaspora in Central Asia and its Trade. Leiden: Brill.

Lieber, Dov 2017. 'Afghan Baby gets Life-Saving Treatment in Israel through Social Media Path'. Times of Israel, 24 February.

Loizos, Peter 1999. 'Ottoman Half Lives: Long-term Perspectives on Particular Forced Migrations'. Journal of Refugee Studies 12 (2): 237 $-263$

Loy, Thomas 2016. Bukharan Jews in the Soviet Union: Autobiographical Narrations of Mobility, Continuity and Change. Wiesbaden: Ludwig Reichert Verlag.

Mahmood, Saba 2015. Religious Difference in a Secular Age: A Minority Report. Princeton: Princeton University Press.

Makdisi, Usama 2019. Age of Coexistence: The Ecumenical Frame and the Making of the Modern Arab World. Berkeley: University of California Press.

Marsden, Magnus 2018. 'Beyond Bukhara: Trade, Identity and Interregional Exchange across Asia'. History and Anthropology 29 (supp. 1), 84-100.

Marsden, Magnus Forthcoming. Beyond the Silk Roads: Trade, Mobility, and Geopolitics across Eurasia. Cambridge: Cambridge University Press.

Massot, Sophie 2013. 'Economic Migrations from Uzbekistan to Moscow, Seoul, and New York: Sacrifice or Rite of Passage?' In M. Laruelle (ed.), Migration and Social Upheaval as the Face of Globalization in Central Asia. Leiden: Brill, pp. 283-299.

Nissimi, Hilda 2003. 'Memory, Community, and the Mashhadi Jews during the Underground Period'. Jewish Social Studies 9 (3): 76-106.

Nunan, Timothy 2016. Humanitarian Invasion: Global Developments in 
Cold War Afghanistan. Cambridge: Cambridge University Press.

O'Halpin, Eunan 2016. 'The Fate of Indigenous and Soviet Central Asian Jews in Afghanistan, 1933-1951'. Holocaust and Genocide Studies, 30 (2): 298-327.

Salemink, Oscar 2016. 'Described, Inscribed, Written Off: Heritagisation as (Dis)connection'. In P. Taylor (ed.), Connected E Disconnected in Viet Nam: Remaking Social Relations in a Post-socialist Nation. Canberra: Australian National University Press, pp. 311-345.

Shanes, Eric 2000. Jake's Legacy: A History of Whittingehame College. London: The Whittingehame Club.

Shield, Renee 2003. Diamond Stories: Enduring Change on the 47th Street. Ithaca: Cornell University Press.

Zenner, Walter 2000. A Global Community: The Jews from Aleppo, Syria. Detroit: Wayne State University Press.

\section{Non Academic Sources}

Abraham-Klein, Dahlia. 2014. Silk Road Vegetarian: Vegan, Vegetarian and Gluten Free Recipes for the Mindful Cook. Rutland, Vermont: Tuttle Publishing.

Cordell, Lilian 2017. Miriam's Table: The Bukharian Cookbook. Peterborough: Fastprint Publishing.

Fein, Esther B. 1984. 'Captive Nations Week Begins With a Protest of Soviet Rule'. New York Times, 16 July.

Jalallar, Muhammad Khan 2012. Rumi Tomato: Autobiography of an Afghan Minister. Muhammad Khan Jalllar: USA.

Mehrdad, Ezzatullah 2018. 'Afghanistan's Last Jew Fights to Keep his Home - The Country's Sole Synagogue'. Times of Israel, 28 November.

Robbins, Liz 2017. 'After Terror Attack, Uzbek Community Faces Unwanted Attention, Again'. New York Times, 6 November. 